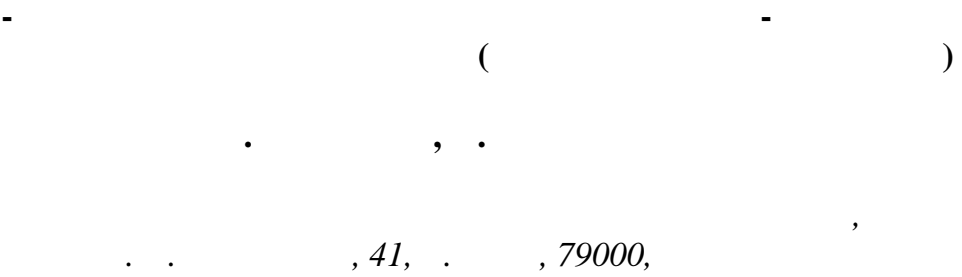

озріз нжулів якн йповніше репрезентує лесово-грунтову серію північної ч стини одільської височини, у будові якої ще зн чн потужність верхньоплейстоценових лесів, одн к уже н рост є потужність лесів середнього плейстоцену.

ведено дет льний опис розрізу т інженерно-геологічні вл стивості порід усіх виділених горизонтів і підгоризонтів, т кож результ ти вивчення впливу великої п леомерзлотної структури н вл стивості лесів. е зроблено н прикл ді псевдоморфози л новецького п леокріогенного ет пу.

лючові слов : леси, похов ні грунти, інженерно-геологічні вл стивості, прос дочність, п леокріогенез, оділля.

озріз нжулів - опорний, розт шов ний поблизу с. нжулів новецького р-ну ернопільської обл., н вододільній рівнині ернопільського пл то, н лівому березі p. углівк у к р'єрі цегельного з воду. ін якн йповніше репрезентує лесово-грунтову серію північної ч стини одільської височини, будов якої є перехідною між вл сне волинськими і подільськими розріз ми. ут ще зн чн потужність верхньоплейстоценових лесів, вони ще добре стр тифіков ні, проте н рост $є$ потужність московських (киснево-ізотопн ст дія V) і дніпровських (киснево-ізотопн ст дія V ) лесів, розділених коршівським викопним грунтовим комплексом (киснево-ізотопн ст дія $\mathrm{V}$ ). уже розвинені н івнічному оділлі п леокріогенні процеси як структурні (головно соліфлюкційні), т к і структурні (низк різновікових псевдоморфоз по полігон льножильних льод х) верхньо- і середньоплейстоценового віку. озріз нжулів стр тотиповий для $л$ новецького $n$ леокріогенного ет $n y$ - одного із п леокріогенних ет пів у меж х відкл дів киснево-ізотопної ст дії $\mathrm{V}$.

еоморфологічно - це мельницьке пл то оділля [7], по суті, відроги вр тинської височини, що високо піднят , з розчленов ним рельєфом, дуже цік вої геологічної будови, н що звернув ув гу . ск рев $[4,5]$, виділивши тут буглівські $ш$ ри.

н решті, у р йоні сіл нжулів, углів, гризківці відкрито низку верхньо- і середньоп леолітичних п м'яток [6]. ет льне вивчення опорного розрізу допоможе відтворити п леогеогр фічні і стр тигр фічні умови прожив ння д вньої людини.

ведемо дет льний опис розрізу н нжулів опорний (див. рис. 1).

уч сний чорноземоподібний грунт $(1)^{1}$ інтенсивно порулибин , м ений к р'єрними робот ми. ілянк ми гумусовий горизонт $0,0-1,0$ знятий повністю. $є$ добре диференційов ний профіль.

\footnotetext{
1 тр тигр фічні горизонти і підгоризонти згідно зі стр тигр фічною схемою $[1,2]$

(c) огуцький ., олошин ., 2012
} 

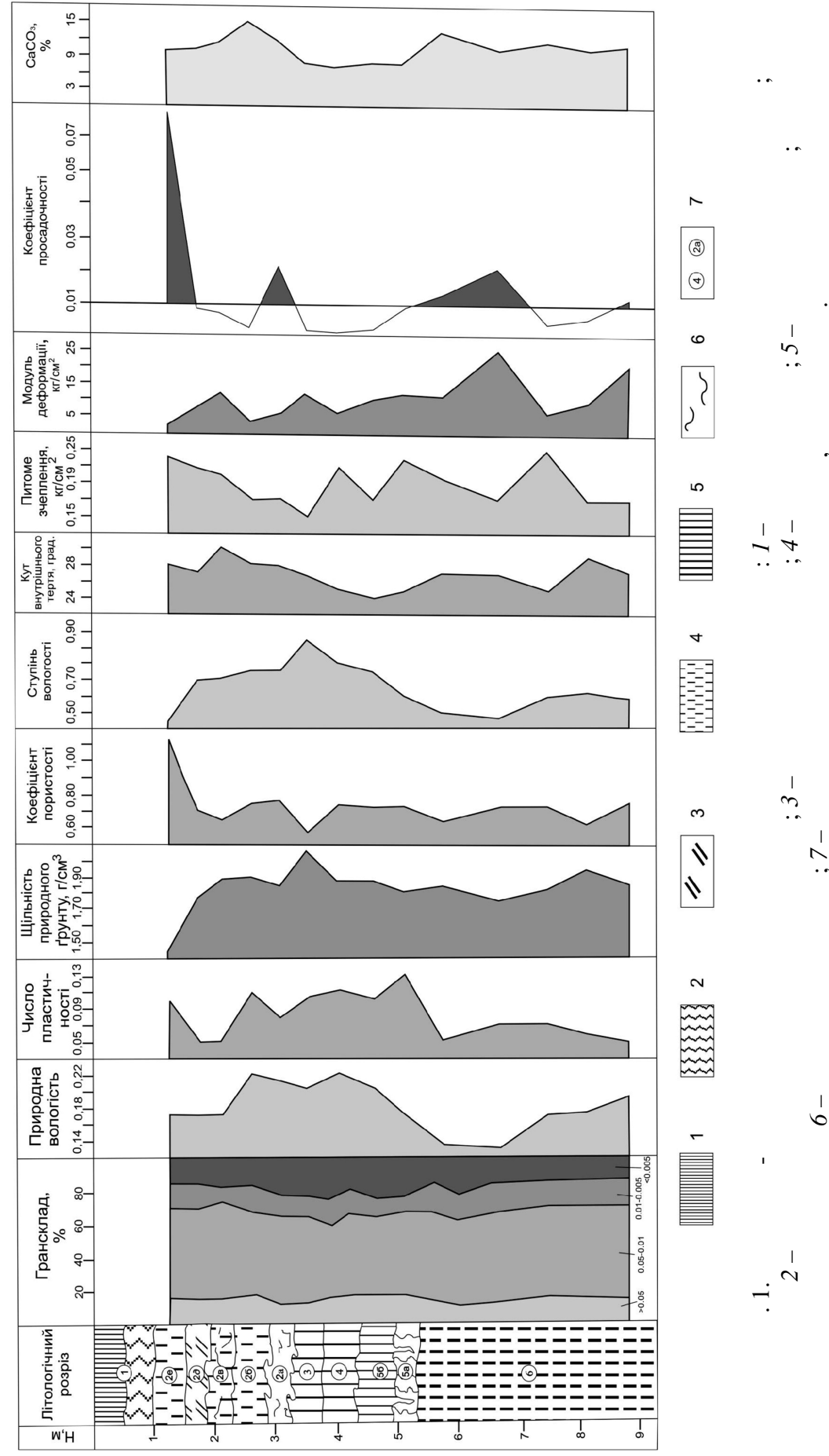
оризонт потужністю до 0,5 м скл дений суглинк ми темносірими, щільними, проте з великою кількістю м кропор і н віть невеликих (до 0,5 см у ді метрі) к верн. міщує велику кількість коріння рослин, червоточин (до 2 см ді метром). ерехід поступовий, $з$ кольором.

оризонт крб., кротовинний М Є потужність до 0,5 м. кЛ дений пухкими суглинк ми, к рбон тними, з великою кількістю кротовин (до 10 см у ді метрі), з повнених головно м тері лом гор. углинки сірі т жовтув то-сірі. ід нижнього конт кту горизонту у підстильні породи регулярно (через 0,5-0,7 м) відходять глибокі (до 1 м і більше) трішини, вкриті білими к рбон тними кірк ми.

ідгоризонт $2 e-\mathrm{м}$ теринськ пород суч сного грунтоутворення. е легкі суглинки, к рбон тні, п леві, з окремими кротовин ми, невеликою кількістю червоточин, в пняковими дутик ми (до 5 см ді метром), поодинокими смуг ми бурого оз лізнення, що відобр ж ють неповносітч сту посткріогенну текстуру порід. исот сітки - до 1,0 см. ерехід поступовий, 3 зрост нням щільності порід.

p силівський підгоризонт (2д). углинки легкі, до супісків, cipi, голубув то-сірі, з добре вир женою неповносітч стою посткріогенною текстурою (висот сітки - до 1,0 см, ширин - до 2 см). осткріогенн текстур відобр жен плівк ми бурого оз лізнення. муги і плівки бурого оз лізнення з фіксов ні й по нижньому конт ктові ш ру. ш рі велик кількість к рбон тних дутиків (до 5,0 см у ді метрі), їх особливо б г то біля нижнього конт кту ш ру.

івненський підгоризонт (26). кл дений суглинк ми легкими, щільними, сірими, голубув то-сірими, неповносітч стими (висот сітки - до 1,5 см, ширин - до 2 см). ш рі 6 г то плям оз лізнення, рідше тр пляються плями оглеєння, нем ло к рбон тних дутиків. ід верхнього конт кту ш ру ч сто відходять тріщини, інкрустов ні 3. ижній конт кт скл днохвилястий, виділений смуг ми бурого оз лізнення.

ижній підгоризонт верхнього горизонту верхньоплейстоценових лесів (2б). кл дений суглинк ми п левими, з плям ми оглеєння і оз лізнення, щільними, проте м кропористими, з численими тріщин ми, інкрустов ними 3. ижній конт кт нерівний, проводимо по поверхні грив дубнівського грунту.

ідгоризонт н ддубнівської соліфлюкції (2 ). отужність ш ру мінлив , $з$ відхиленнями $\pm 0,2$ м. удов п чки гривист . грив х перев ж є м тері л дубнівського викопного грунту (голубув то-сірі суглинки) і лес, який уміщує ці гриви. отужність грив - до 0,1 м. они незвично вигнуті, по периметр х інтенсивно оз лізнені. ш рі тр пляються еліпсоподібні включення (по довгій осі еліпс - до 0,3 м, по короткій - 0,2 м) пухкого, просякнутого псевдоміцелієм лесу. ижній конт кт скл днохвилястий, підкреслений смуг ми бурого оз лізнення. 
убнівський викопний грунт (3). кл дений в жкими суглин$3,3-3,8$ к ми (до глин), твердо-пл стичними, сірими, голубув то-сірими, щільними, плік тивно деформов ними. нижній ч стині ш ру простежуються скл днохвилясті лінзи потужністю до 5,0 см, скл дені сильно гумусов ним м тері лом, сірим, темно-сірим (до гітії). ш рі б г то включень пухкого к рбон тного лесу, н йч стіше дуже різном нітної форми, з м ксим льними розмір ми до 0,3 м т інтенсивним оз лізненням по периметр х. ш рі нем ло кр пкових з лізисто-м нг нових прим зок і тріщин 3 п тьок ми 3 по стінк х. о нижньому конт ктові ортз нд до 3,0 см товщиною.

ижній горизонт верхньоплейстоценових лесів (4). є дуже мінливу $(0,2-0,6$ м) потужність. кл дений суглинк ми ясносірими, світло-коричневими, з плям ми оз лізнення до 5,0 см у ді метрі і численними кр пковими з лізисто-м нг новими прим зк ми. одекуди у ш рі тр пляється неповносітч ст посткріогенн текстур (висот сітки - до 1,0 см, ширин - до $2 \mathrm{~cm}$ ), виділен плівк ми бурого оз лізнення. ш рі численні лінзи і гриви гумусов них суглинків гор. горохівського викопного грунтового комплексу, що з ляг є нижче, товщиною до 0,15 м.

p ктично н всю потужність (включ ючи м ксим льні ï зн чення) нижній горизонт верхньоплейстоценових лесів розрізу

нжулів порушений соліфлюкційними процес ми. риви суглинків гор. горохівського викопного грунтового комплексу вир зно “просвічуються" і в дубнівському грунті, тобто н д добре вир женим нижнім ортз ндом дубно.

орохівський викопний грунтовий комплекс (5). втоморфний в рі нт, м є добре вир жений генетичний профіль.

оризонт потужністю до 0,6 м і більше. кл дений суглинк ми темно-коричневими (шокол дними), щільними, проте м кропористими. ерхня ч стин, місцями і н всю потужність, порушений соліфлюкцією, ун слідок чого нерідко н був є рис чіткої хвилястої ш рув тості і вмішує лінзочки (1,0-1,5 см товщиною) жовтув то-коричневих суглинків гор. . ід нижнього конт кту ш ру відходять добре вир жені язики-косми, н йч стіше н хилені по п леорельєфу. ертик льн потужність косм - до 1,0 м, горизонт льн - до 0,1 м, відст нь між ними - до 1,0 м, зрідк більше.

оризонт потужністю 0,4 м і більше скл дений суглинк ми жовтими, жовтув то-коричневими, щільними, інтенсивно біогенно переробленими (по всьому ш ру велик кількість червоточин і кротовин із н повнюв чем з гор. горохівського комплексу). углинки відмиті від к рбон тів, з інтенсивними п тьок ми гумусу. ижній конт кт чіткий, хвилястий, з зміною кольору $\mathrm{i}$ появою з кип ння з 1, зменшується т кож щільність порід.

ерхній горизонт середньоплейстоценових лесів (6). кл де-

$4,0-4,8$ 
ком, сильно к рбон тний (дутики, пилув ті к рбон ти, псевдоміцелій, н льоти по тріщин х). ерх ш ру переповнений червоточин ми (ді метром до 2,0 см), сп льними к мер ми землериїв (до 15,0 см), кротовин ми (до 7,0 см). н повнюв чі червоточин, сп льних к мер, кротовин головно м тері л гор. , рідше - гор. горохівського викопного грунтового комплексу. іогенн переробленість фіксов н здебільшого до глибини 1,0 м від поверхні ш ру. ілянк ми тут чітк ш рув тість, що зумовлен тонкими (1-2 мм, зрідк більше) прош рк ми і лінзочк ми пісків. нижній ч стині ш ру велик кількість кр пкових 3 лізистом нг нових прим зок, зрідк тр пляються плями оглеєння.

східній ч стині к р'єру в цьому ш рі виявлено і досліджено середньоплейстоценову псевдоморфозу по полігон льножильних льод х (рис. 2).

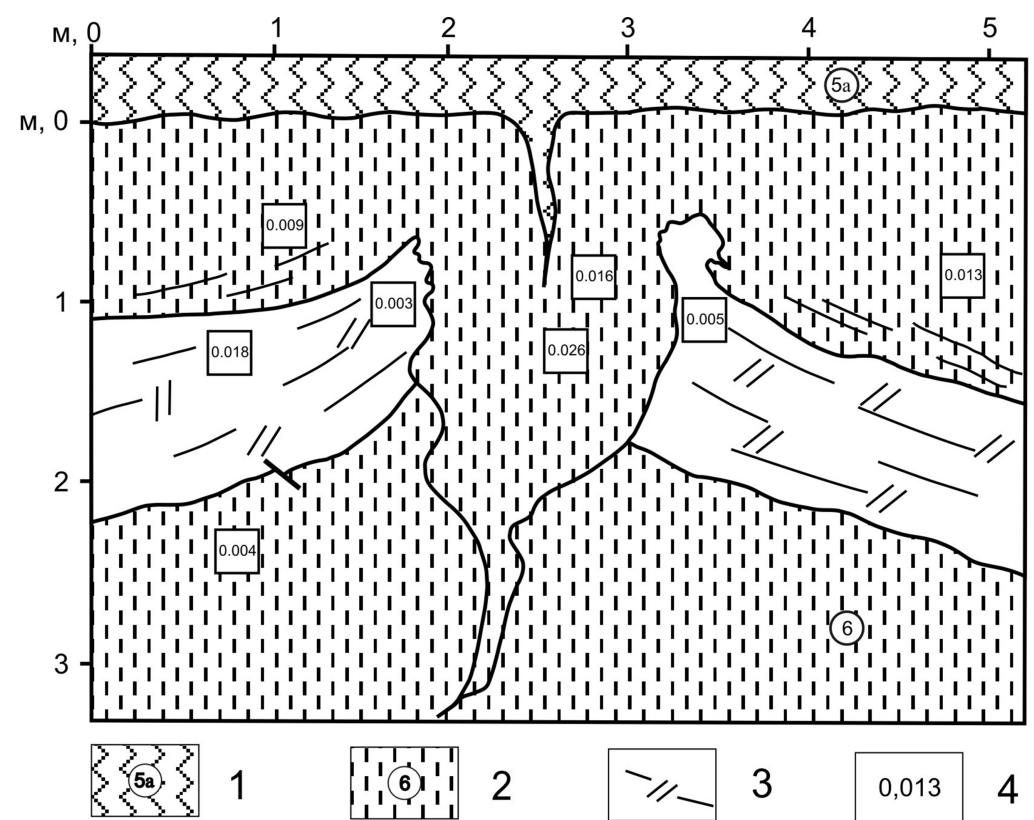

ис. 2. севдоморфоз по полігон льно-жильних льод х л новецького п леокріогенного ет пу: 1 - горизонт $I$ горохівського викопного грунтового комплексу; 2 - леси верхнього горизонту середньоплейстоценових лесів; 3 - похов ний діяльний ш р; 4 - відносн прос дочність 3 вертик льного н в нт ження 0,3

ї вертик льн потужність досяг є 2,5 м, м ксим льн ширин - 1,2 м. умовний нуль у ході опису й опробув ння прийнято підошву гор. горохівського комплексу. севдоморфоз з мик ється н соліфлюкційно деформов ній п чці (л новецький підгоризонт). е супіски оглеєні, голубув то-сірі, щільні, з хвилястими смуг ми бурого оз лізнення, розбиті трішин ми. окремих ділянK X 3 фіксов но посткріогенну текстуру з висотою і шириною сітки 1-2 см. екстурні окремості вир зно виділені бурим оз лізненням. 
д псевдоморфозою з ляг є ш р середньоплейстоценового лесу. ін п левий, з кротовин ми і червоточин ми, біля нижнього конт кту більше оглеєний і оз лізнений, розш ров ний, соліфлюкційно деформов ний, з дутик ми. о нижньому конт ктові чітк смуг оз лізнення. ес розбитий тріщин ми, інкрустов ними 3. ід л новецьким підгоризонтом з ляг є дост тньо однорідний, менше оглеєний лес, зеленкув то-сірий, супіщ ний, вологий. д псевдоморфозою горохівськ косм і п тьоки гумусу по тріщин х. міщені леси сильно деформов ні, підігнуті вгору. повнюв ч псевдоморфози однорідний, комп ктний, дост тньо пухкий, місцями із субгоризонт льною ш рув тістю.

бор торні дослідження порід, виділених у лесово-грунтовій товщі горизонтів і підгоризонтів, з свідчили, що вони відрізняються не лише з морфологічними особливостями, й з скл дом т фізико-мех нічними вл стивостями (див. рис. 1).

гр нулометричним скл дом, як і в опорних розріз х олинської височини, грунти ${ }^{2}$ лесових і п леогрунтових горизонтів суттєво відрізняються від викопних грунтів 3 вмістом усіх фр кцій. ількість тонкого піску (0,1-0,05 мм) у лес х змінюється від 6 до $15 \%$, у викопних грунт х досяг є $18 \%$. йбільший вміст піску з фіксов но в гумусовому горизонті горохівського викопного грунтового комплексу.

онцентр ція вл сне пилув тих ч стинок $(0,05-0,01$ мм) у лесових горизонт х змінюється від 37 до $54 \%$ і пересічно ст новить $45 \%$. глибиною їхній вміст дещо зменшується. вмістом цієї фр кції викопні грунти відрізняються від лесів менш суттєво. онтр стніші відмінності є 3 концентр цією глинистих $(<0,001$ мм) ч стинок. лесових горизонт х їхній вміст змінюється від 16 до $24 \%$, у викопних грунт х - від 21 до $27 \%$. йвищ їхня кількість з фіксов н у грунт х горохівського викопного грунтового комплексу, н йнижч - у середньоплейстоценових лес х.

і п зон зміни зн чень природної вологості в меж х лесово-грунтової п чки досить великий. ї бсолютні зн чення змінюються від 0,13 до 0,22. г лом простежується тенденція до збільшення вологості від підошви суч сного грунту і горохівського викопного грунтового комплексу. ід суч сним грунтом вологість лесів ст новить 0,17 і зрост є до 0,22, під горохівським комплексом підвищується від 0,13 до 0,19. е пояснюють як різницею у вмісті глинистих ч стинок у с мих лес х, т к і екр нув льними т водоутримув льними вл стивостями грунтових горизонтів. йвологішими $(0,22) \in$ породи нижнього підгоризонту верхнього горизонту верхньоплейстоценових лесів т нижнього горизонту верхньоплейстоценових лесів, що сформов ні н д викопними грунт ми. г лом леси верхнього плейстоцену м ють зн чно вищу вологість порівняно з середньоплейстоценовими.

числом пл стичності лесов товщ чітко розділен н три ч стини: верхню - породи верхнього і нижнього горизонтів верхньоплейстоценових лесів з числом пл стичності $0,05-0,12$; середню -дубнівський і горохівський викопні грунти з числом пл стичності 0,08-0,13; нижню - леси середнього плейстоцену з числом пл стичності $0,05-0,07$.

2 інженерній геології під грунт ми розуміють усі породи, які є середовищем бо основою споруд. 


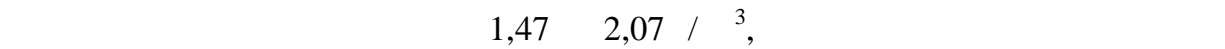
внутрішню будову лесової товщі. йменше зн чення цього пок зник м є н йпухкіш ч стин верхнього горизонту верхньоплейстоценових лесів, як з ляг є безпосередньо під суч сним грунтом і ч стково змінен процес ми суч сного грунтотворення. ещо вищ щільність підгоризонтів оглеєння і соліфлюкції (кр силівський і рівненський

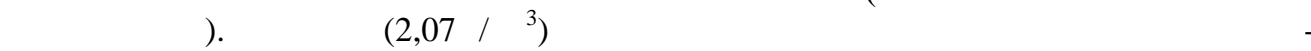
копному грунту. зн чимо, що щільність лесових “пирогів", які тр пляються в дуб-

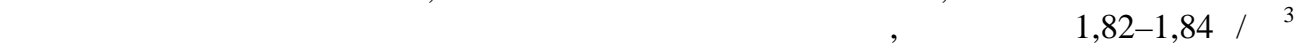
менше. н логічні з кономірності вл стиві й коефіцієнту пористості, який з бсолютним зн ченням змінюється від 1,15 для лесів верхнього підгоризонту верхнього горизонту верхньоплейстоценових лесів до 0,57 для дубнівського викопного грунту.

рос дочність грунтів, зн чення якої з лежить від щільності, вологості т глинистості, змінюється від 0 до $7 \%$. иявляється вон фр гмент рно у н йпухкіших і н йменш вологих грунтових відмін х лесів верхнього т середнього плейстоцену. ільніші і вологіші грунти підгоризонтів оглеєння і соліфлюкції т викопні грунти прос дочних вл стивостей не м ють. кі з кономірності х р ктерні й для інших р йонів олино- оділля [3].

ок зники кут внутрішнього тертя змінюються від 24 до $30^{\circ}$. хні м ксим льні зн чення х р ктерні для н йщільніших і м ловологих лесових підгоризонтів. викопних грунт х зн чення кут внутрішнього тертя менші, їхні мінім льні зн чення $\left(24^{\circ}\right)$ вл стиві пород м гумусового горизонту горохівського викопного комплексу.

итоме зчеплення колив ється від 0,15 до $0,23 \mathrm{kг} / \mathrm{cm}^{2}$. меж х лесово-грунтової товщі воно змінюється нез кономірно. інім льні зн чення цього пок зник , н відміну від $б$ г тьох лесових розрізів олинської височини, з фіксов но у дубнівському викопному грунті. томість н йвищі зн чення прит м нні лесовим горизонт м. евну деструктивну роль тут може відігр в ти н явність посткріогенної текстури, як знижує міцність грунту.

одуль 3 г льної деформ ції тісно корелює зі скл дом т водно-фізичними вл сти-

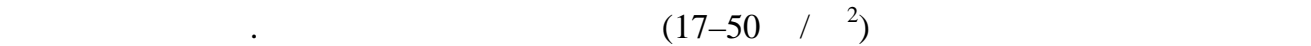
відмін лесів. йщільніші т сильно оз лізнені грунти рівненського підгоризонту, дубнівського викопного грунту, горизонту горохівського викопного грунтового комплексу т лесів середнього плейстоцену м ють підвищений модуль деформ ції, який колив ється від 100 до $150 \mathrm{Kг} / \mathrm{cm}^{2}$.

д ними к льциметричних досліджень, вміст к рбон тів к льцію у лес х верхнього горизонту верхньоплейстоценових лесів ст новить 10-15\%. дубнівському викопному грунті, лес х нижнього горизонту верхньоплейстоценових лесів т горохівському викопному грунтовому комплексі їхня кількість зменшується до $8 \%$, зрост ючи до $10-15 \%$ у лес х середнього плейстоцену.

н ліз розподілу пок зників скл ду і вл стивостей лесових, п леогрунтових і п леокріогенних горизонтів свідчить про суттєву їхню відмінність, зумовлену особливостями п леогеогр фічних умов їхнього формув ння т ді генетичного перетворення.

ля оцінки впливу однієї з кріогенних структурних деформ цій (див. рис. 2) н фізико-мех нічні вл стивості грунтів відібр но і досліджено вісім зр зків грунтів непорушеної структури (монолітів).

роведені дослідження з свідчили, що н повнюв ч структури м є невисоку природну вологість $(0,10-0,12)$, він недоущільнений (коефіцієнт пористості пересічно ст новить 0,75$)$, ступінь вологості змінюється в меж х 0,36-0,44. вдяки високій пористості 
т незн чній вологості, високому вмісту крупнопилув тих ч стинок (пон д 53 \%) грунти н повнюв ч м ють прос дочні вл стивості в р зі їхного зволоження. оєфіцієнт прос дочності ст новить 0,016-0,026 з вертик льного н в нт ження 0,3 . і грунти м ють зд тність просід ти т кож і з природного тиску грунтів, що з ляг ють вище. оефіцієнт зменшення модуля деформ ції в р зі зволоження грунту ст новить 2,5. томість грунти, що містяться у приконт ктовій зоні псевдоморфози і з зн ли іiі ущільнюв льного впливу, м ють підвищену щільність (коефіцієнт пористості пересічно ст новить 0,67). они непрос дочні не лише 3 природного, й 3 дод ткового н в нт ження. оефіцієнт зменшення модуля деформ ції в р зі н сичення грунтів водою ст новить 1,8 .

трим ні результ ти д ють змогу стверджув ти, що формув ння полігон льножильних структур призводило до ущільнення вміщених порід, яке з зн ченням коефіцієнт пористості перевищує $10 \%$. обто морозобійні тріщини великого розміру є своєрідними ном льними зон ми у лесовій товщі (зон ми підвищеної неоднорідності), у меж х яких грунти м ють низькі зн чення мех нічних х р ктеристик т зд тність до просід ння, н прилеглих ділянк х н вп ки - вищі пок зники несучої зд тності. крім того, н повнюв ч псевдоморфоз з вдяки недоущільненості утворює фільтр ційні вікн - зони підвищеної проникності для з бруднених інфільтр ційних вод.

1. огуцкий . . сновные п леокриогенные эт пы плейстоцен юго-з п д осточновропейской пл тформы / . . огуцкий // етвертичный период : методы исследов ния, стр тигр фия и экология. ез. V сесоюз. совещ. - ллинн, 1990. - . 1. - . 65-66.

2. огуцький . . есовий покрив олинської височини / . . огуцький, . . огуцький, . олошин // кр їнське олісся : вчор , сьогодні, з втр : зб. н ук. пр ць. - уцьк : дстир'я, 1998. - . 105-107.

3. огуцкий . . икличность лессовой толщи юго-з п д осточно- вропейской пл тформы и инженерн я стр тигр фия / . . огуцкий, . . олошин // еория цикличности лессов и пр ктике инж.-геол. изыск ний. - . : $\quad$ ук , 1985. - . 111-120.

4. ск рев . ун бугловских слоев олыни / . ск рев // p. еол. ком. ов я серия. б., 1903. - ып. 5. - 142 с.

5. ск рев .. еологические исследов ния в го- п дной оссии ( бщ я геологическ я к рт вропейской оссии, лист 17-й) / . . ск рев // р. еол. ком. ов я серия. - 1914. ып. 77. $-710 \mathrm{c}$.

6. итник . ередній п леоліт оділля / . итник. - ьвів, 2000. - 372 с.

7. ись . . еоморфологія / . . ись. - ьвів : ид-во ьвів. ун-ту, 1962. -224 с.

m ття: н дійшл до редколегї̈ 08.11.2011

прийнят до друку 22.11.2011 


\section{ENGINEERING-GEOLOGICAL CHARACTERISTICS OF THE LOESS-SOIL SERIES ROCKS AT THE KEY PROFILE VANZHULIV (PODILLIA UPLAND)}

\section{A. Bogucki, P. Voloshyn}

Ivan Franko National University of Lviv, . Doroshenko St., 41, UA - 79000 Lviv, Ukraine

In the section Vanzhuliv, the loess-soil series of the northern part of the Podillia Upland is exposed. In this section, the thickness of the Upper Pleistocene loess deposits is still relatively considerable, whereas the thickness of the Middle Pleistocene loess deposits increases.

The detailed description of the section and of the engineering-geological properties of all the distinguished horizons and sub-horizons is given. Besides that, the influence of the large-scale fossil permafrost structure on the properties of loess is described, basing on the example of the pseudomorphic structure of the Lanivtsi paleocriogenic stage. lia.

Key words: loess, paleosoils, engineering-geological properties, subsidence, paleocriogenesis, Podil-

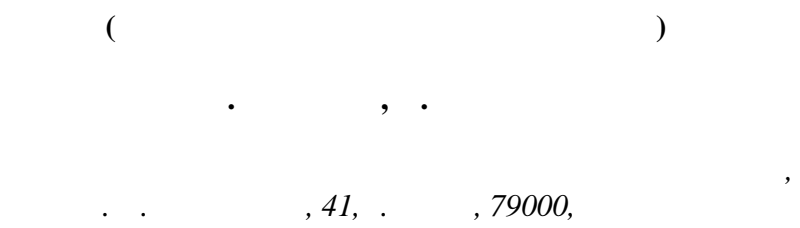

зрез нжулов предст вляет лессово-почвенную серию северной ч сти одольской возвышенности, в строении которой еще зн чительн я мощность верхнеплейстоценовых лессов, но уже н р ст ет мощность лессов среднего плейстоцен .

риведено подробное опис ние $\mathrm{p}$ зрез и инженерно-геологические свойств пород всех выделенных горизонтов и подгоризонтов, т кже результ ты изучения влияния крупной п леомерзлотной структуры н свойств лессов. то сдел но н примере псевдоморфозы л новецкого п леокриогенного эт п .

лючевые слов : лессы, ископ емые почвы, инженерно-геологические свойств , прос дочность, п леокриогенез, одолия. 